\title{
A study of Eagle's syndrome in CMS-TH Bharatpur
}

\author{
Shah DK, ${ }^{1}$ Ganguly SN, ${ }^{2}$ Reddy NS ${ }^{3}$ \\ ${ }^{1}$ Lecturer, ${ }^{2}$ Professor, ${ }^{3}$ Professor and Head, Department of ENT, College of Medical Sciences-TH, \\ Bharatpur, Nepal
}

\begin{abstract}
Objective

To study the common symptoms and outcome of surgical treatment of Eagle's syndrome

\section{Methods}

A total of 22 cases were studied prospectively in both sexes from January 2008 to December 2010, in Department of ENT-HNS College Of Medical Sciences-Teaching Hospital, Bharatpur, Nepal. Patients with symptomatic styloid process were clinically palpated at tonsillar fossa and finally sent for X-ray styloid process. Patients underwent intra-oral tonsillectomy with styloidectomy. Post-operative improvement was analysed by follow up at one three and six months interval.

\section{Results}

Most common age group was 30-40 years (63.63\%) with female dominance ( $M: F=1: 4.5)$. The most frequent symptoms were pain in throat (29.62\%), referred pain in ear (20.37\%), pain in anterior triangle in neck (24.07\%), foreign body sensation in throat (14.81\%) and difficulty in swallowing (11.11\%). Fifty nine percent of patients were having symptoms for last two to four years and $50 \%$ were on medication for last one to two years. All the patients underwent styloidectomy through intra-oral route. $(63.63 \%)$ patients became symptom free and $13.63 \%$ didn't show improvement even after operation.

\section{Conclusion}

Eagle's syndrome is common in young females with various atypical presentations. Dull/throbbing or radiationg throat pain and pain in anterior triangle of the neck are common presentations. Diagnosis is done simply by palpating the tonsillar fossa.

Keywords: Eagle's syndrome, styloid process, styloidectomy, intra-oral route.

\section{INTRODUCTION}

Eagle's Syndrome (ES) or elongated styloid process syndrome was first described by Eagle, an Oto-rhino-

Correspondence: Dr. Dinesh Kumar Shah

E-mail: dineshshh@yahoo.com laryngologist, who first presented two cases with sympatomatology of elongated styloid process in his article in $1937^{1}$. Styloid process is a bony projection located just anterior to stylomastoid foramen, the length of which averages from $20-25 \mathrm{~mm}$. It is of cylindrical 
Journal of College of Medical Sciences-Nepal, 2014, Vol-10, No-1

form and projects downward from inferior surface of temporal bone and the tip of which is situated laterally from the pharyngeal wall and immediately behind tonsillar fossa and critically between internal and external carotid artery. Stylohyoid and stylomandibular ligament extend from styloid process, it is considered elongated when it is more than $30 \mathrm{~mm}$ in size. The facial nerve runs anterior and medial to styloid process. The glossopharyngeal nerve exits through jugular foramen and curves in close proximity under styloid process. The acessory and vagus nerve also runs medial to the styloid process. The approximation of the glossopharyngeal nerve with stylo-hyoid ligament is the basis for glossopharyngeal neurological symptoms seen in Eagle's syndrome.

It is a rare disease and $0.04-0.08 \%$ of population is suffering from it ${ }^{2}$. Incidence of the disease is four percent ${ }^{3,4}$. It is usually asymptomatic, occurs in adult patients ranged from 30-50 years ${ }^{5}$. Females are affected more often than male ${ }^{6}$.

Eagle primarily described two syndromes ${ }^{1}$ -

a. Classic styloid syndrome-It frequently follows tonsillectomy and is characterized by pharyngodynia, localized in tonsillar fossa and sometimes accompanied by dysphagia, odynophagia, hypersalivation, foreign body sensation and more rarely by temporary voice changes.

b. The stylo-carotid syndrome - It is not correlated with tonsillectomy. In this condition the stylo-hyoid apparatus compresses the internal and/ or external carotid arteries and especially their perivascular sympathetic fibres, resulting in a persistent pain, radiating in the carotid territory.
The symptom ranges from mild discomfort to acute neurologic and referred pain. Clinical diagnosis is based on palpating the tonsillar fossa, which will reveal a bony pointed part and exacerbate the pain. Conformation can be made by lateral X-ray film or panorex radiograph, CT scan and $3 \mathrm{D}$ reformatted technique provide more information.

It is frequently misdiagnosed or overlooked as a possible diagnosis of globus hystericus, GERD, pharyngitis, lingual tonsillitis, middle ear infection, neuralgia and so on. Many patients visit multiple doctors and few of them even go for psychiatric evaluation and treatment for long duration. This study was conducted with objectives of determining common symptoms in particular age and sex and outcome after surgical treatment.

\section{MATERIALS AND METHODS}

A total of 22 cases were studied prospectively in both sexes from January 2008 to December 2010, in Department of ENT-HNS College of Medical Sciences-Teaching Hospital, Bharatpur, Nepal. Patients with symptomatic styloid process were clinically palpated at tonsillar fossa and finally sent for $\mathrm{X}$-ray styloid process with a requisition form to the radiology department; patients underwent intra-oral tonsillectomy with styloidectomy. Post-operative improvement was analysed by follow up at one three and six months interval.

\section{Results}

Table 1: Sex distribution of cases

\begin{tabular}{|lcc|}
\hline Sex & No of patients & Percentage \\
\hline Male & 4 & 18.18 \\
Female & 18 & 81.81 \\
\hline
\end{tabular}


Shah DK et al. A study of Eagle's syndrome.

Table 2: Age distribution:

\begin{tabular}{ccc|}
$\begin{array}{c}\text { Age range } \\
\text { (in years) }\end{array}$ & $\begin{array}{c}\text { No } \\
\text { of patients }\end{array}$ & Percentage \\
$<20$ & 0 & 0 \\
$20-30$ & 2 & 9.09 \\
$30-40$ & 14 & 63.63 \\
$40-50$ & 5 & 22.72 \\
$>50$ & 1 & 4.55 \\
\hline
\end{tabular}

Table 3: Frequency of symptoms presentation

\begin{tabular}{lcc|}
$\begin{array}{l}\text { Presenting } \\
\text { symptoms }\end{array}$ & $\begin{array}{c}\text { No. of } \\
\text { symptoms }\end{array}$ & Percentage \\
$\begin{array}{l}\text { Dull/ Throbbing/ } \\
\text { Radiating throat pain }\end{array}$ & 16 & 29.62 \\
$\begin{array}{l}\text { Pain in anterior } \\
\text { triangle of neck }\end{array}$ & 13 & 24.07 \\
Referred pain in ear & 11 & 20.37 \\
FB sensation in throat & 8 & 14.81 \\
Difficulty in swallowing & 6 & 11.11 \\
\hline Total & $\mathbf{5 4}$ & $\mathbf{1 0 0}$ \\
\hline
\end{tabular}

\section{Table 4: Duration of symptoms}

\begin{tabular}{|ccc|}
$\begin{array}{c}\text { Duration of } \\
\text { symptoms }\end{array}$ & $\begin{array}{c}\text { No. of } \\
\text { patients }\end{array}$ & Percentage \\
\hline$<2$ years & 7 & 31.18 \\
2 -4 years & 13 & 59.09 \\
$>4$ years & 2 & 9.09
\end{tabular}

Table 5: Duration of medication taken

\begin{tabular}{|ccc|}
$\begin{array}{c}\text { Duration of } \\
\text { medication }\end{array}$ & $\begin{array}{c}\text { No of } \\
\text { patients }\end{array}$ & Percentage \\
\hline 1 year & 11 & 50 \\
\hline 1-2 years & 8 & 36.36 \\
\hline 2-3 years & 3 & 13.63 \\
\hline
\end{tabular}

Table 6. Outcome of the patients

\begin{tabular}{|ccc|}
$\begin{array}{l}\text { Follow up } \\
\text { findings }\end{array}$ & $\begin{array}{c}\text { No. of } \\
\text { patients }\end{array}$ & Percentage \\
\hline $\begin{array}{l}\text { Symptom free } \\
\text { Mild to moderate } \\
\text { improvement }\end{array}$ & 14 & 63.63 \\
No improvement & 3 & 22.72 \\
\hline
\end{tabular}

In the period of 2008 to 2010,22 patients with symptomatic styloid process were studied in which 18 were females and four males, with $\mathrm{M}: \mathrm{F}=1: 4.5$ (table 1). The common age of presentation of symptoms was $30-40$ years contributing to 14 (63.63\%) cases. Only one case presented with the symptoms of the age of 50 years and those under the age of 20 years were nil (table 2). As represented in table 3, the most common presentation was throat pain $(29.62 \%)$ followed by anterior triangle of neck $(24.07 \%)$, referred pain in ear $(20.37 \%)$, foreign body sensation in throat (14.81\%) and difficulty in swallowing (11.11\%). Most of the patients were symptomatic for last two to four years $(n=13,59.09 \%)$ (table 4). Most of the patients were misdiagnosed as globus hystericus, recurrent tonsillitis, GERD, ETD and many others by psychiatric 
Journal of College of Medical Sciences-Nepal, 2014, Vol-10, No-1

and other practitioners. As shown in table 5, 11 were under medication since last one year and eight patients for one to two years, spending resources in medication and various investigations. Many of them were having fear of some chronic disease and cancer due to various visits and prolong medication.

Suspicion of elongated styloid process was done on the basis of various symptoms given by the patient in ENT OPD and it was clinically diagnosed by digital palpation of styloid process in tonsillar fossa, which was causing aggravation of symptoms on applying pressure over the region. The diagnosis was confirmed by radiology. Finally patients were counseled for styloidectomy and it was done through intra-oral route under general anesthesia. After that, patients were followed up in one, three and six months. Most of the patients (14) relieved from the symptoms with lots of happiness. Five patients had mild to moderate improvement and three patients showed no improvement. So we started carbamazepine $200 \mathrm{mg}$ three times a day in eight little to not improved patients, among which six were improving and only two were not improved at all after three months follow up (table 6).

\section{DISCUSSION}

Styloid process develops from second branchial arch consisting of styloid process, stylohyoid ligament, mandibular ligament, hyoid with thyroid cartilage and muscles attached to the styloid process are stylohyoid, styloglossus, stylopharyngeus. It consists of following parts ${ }^{7}$.

1. Tympanohyal part: the base of styloid process

2. Stylohyal part: Forms a large part of styloid process
3. Ceratohyal part: Precursor of stylohyoid ligament

4. Hyohyal part: Development precedes the small horn of hyoid bone

It is believed that the ceratohyal part of the second branchial arch contains small parts of embryological cartilage that may or may not mature at later stage into bone. The commonly proposed theories about the actual cause of elongation of styloid process are congenital elongation of styloid process, calcification of stylohyoid ligament by an unknown process and growth of osseous tissue where the stylohyoid ligament inserts $^{8,9}$.

In daily practice, the diagnosis of ES is usually made in specialist clinics and is mostly made by ORL-HNS specialists and maxillofacial surgeons. Its average length is $20-25 \mathrm{~mm}$ and is said to be enlarged when its length is greater than $25 \mathrm{~mm}$. It is mostly seen in young females at the age of 30-50 years. Lateral or medial deviation from the carotid bifurcation will cause pressure over external or internal carotid arteries causing stimulation of the sympathetic nerve plexus along its distribution causing symptoms. Facial pain by impingement and stimulation of external carotid artery plexus may develop. Irritation of other nerves like glossopharyngeal, hypoglossal, facial, chorda tympani, trigeminal and vagus nerve which are nearby styloid process also gets stimulated and causes neuralgic cervico-facial pain. Other possible cause of it are like inflammation of Eustachian tube, middle ear, parotid disease, impeded eruption of upper and lower impacted or retained wisdom teeth, any sort of cervico-facial trauma, malignant diseases like malignancy of nasopharynx, larynx, base of tongue, tonsil etc.

There are various symptoms presentation like- 
Shah DK et al. A study of Eagle's syndrome.

1. Dysphagia/FB sensation in throat

2. Symptoms aggravates on mouth opening, yawning, rotating head etc

3. Otalgia- mostly sharp shooting types, last for only couple of minutes

4. Cervical/cervico-facial pain/facial pain/ retromandibular pain

5. Pain in anterior triangle of neck

6. Headache in area of orbit and other area supplied by carotid artery

7. Temporary dizziness and flushing light in front of eyes, which comes on movement of head and neck or during swallowing

\section{Past history of tonsillectomy}

The disease is simply diagnosed clinically by digital palpation of tonsillar fossa in which sharp pointed hard structure can be felt which on applying pressure causes increase in symptoms. It can be confirmed radiologically by doing panoramic radiograph and antero-posterior view radiograph or to measure actual length of styloid process, CT scan can be done. Treatment of ES is both medical and surgical. Medical treatment includes the assurance, NSAID, steroid+ lignocaine intralesional injection, antiepileptic drugs, anti-histaminic drugs. Surgical treatment includes styloidectomy by external neck approach or intra-oral approach. But I generally prefer intra-oral route because it is easy to do, less chance of bleeding, less time consuming, less chances of complication and no external neck scar.

In spite of its simplicity in diagnosis, most of the patients spend lots of resources in this disease due to misdiagnosis by the various practitioners, many of them also undergo repeated psychiatric evaluation. So it is responsibility of ORL-HNS specialists to diagnose the disease by simply palpating styloid process if probable symptoms are given by the patients.

\section{CONCLUSION}

Eagle's syndrome is common in young female with various atypical presentations. Dull/ throbbing or radiating throat pain, pain in anterior triangle of neck, referred pain in epsilateral ear, foreign body sensation in throat, difficulty in swallowing were common presentations in our study. Diagnosis of this disease is simple, i.e. simply by palpating the tonsillar fossa.

\section{REFERENCES}

1. Eagle WW . Elongated styloid process: Report of two cases. Arch Otolaryngol 1937; 25:584-6.

2. Baddour HM, Anear JT, Tilson AB, et al. Eagle's syndrome report of case. J. Oral Surg 1978; 36(6):486.

3. Eagle WW. Elongated styloid process: "Further observations and a new syndrome". Archives of Otolaryngology 1948;47(5):630-40.

4. Prasad KC, Kamath MP, Reddy MJ, et al. Elongated styloid process (Eagle's syndrome): A clinical study .Journal of Oral and Maxillo-Facial Surgery 2002; 66 (2):171-5.

5. Murtellaro C, Biancucci P, Picciolo G, et al. Eagle's syndrome: Importance of corrected diagnosis and adequate surgical treatment. Journal of CrainoFacial Surgery 2002;13(6):755-8. 
Journal of College of Medical Sciences-Nepal, 2014, Vol-10, No-1

6. Fini G, Gasparini G, Filippini F, et al. The long styloid process syndrome or Eagle's syndrome. Journal of Cranio-Maxillo-Facial Surgery 2000;28(2):123-7.

7. Sebastijan S, Klara S. Styloid process syndrome. Acta Stomatol Croat 2000;34 (4):451-6.
8. Balbuena L, Hayes D, Ramirez S, et al. Eagle's syndrome (elongated styloid process). South Med J 1997; 90:331-4.

9. Camarda AJ, Deschamps C, Forest D. Stylohyoid chain ossification: A discussion of etiology. Oral Surg Oral Med Oral Pathol 1989;67:508-14. 